\title{
FORMULATION AND PHYSICAL EVALUATION OF MICROEMULSION AND W/O/W MULTIPLE EMULSIONS DOSAGE FORMS WITH ALPHA ARBUTIN, LACTIC ACID, AND NIACINAMIDE AS SKIN-WHITENING COSMETICS
}

\author{
SILVIA SURINI*, TINA MELLANI
}

Department of Pharmacy, Faculty of Pharmacy, Universitas Indonesia, Depok 16424, Indonesia. Email: silvia@farmasi.ui.ac.id

Received: 21 April 2017, Revised and Accepted: 20 August 2017

\begin{abstract}
Objective: The present study aimed to formulate and determine the physical stability of microemulsion and W/O/W multiple emulsions, containing $\alpha$ arbutin, lactic acid, and niacinamide, as skin-whitening cosmetics.
\end{abstract}

Methods: A skin lightening effect can also be obtained from lactic acid, which accelerates the turnover of pigmented cells in the epidermis, and from niacinamide, which inhibits the transfer of melanosomes from melanocytes to keratinocytes. These active ingredients were combined in microemulsion and W/O/W multiple emulsions dosage forms in various concentrations of Tween 80 as an emulsifier. An evaluation and physical stability test were carried out during 12 weeks of storage at $28 \pm 2^{\circ} \mathrm{C}, 4 \pm 2^{\circ} \mathrm{C}$, and $40 \pm 2^{\circ} \mathrm{C}$, as well as a cycling test.

Results: The results showed that a microemulsion could be prepared in 25-35\% of Tween 80 (surfactant) and 10\% of ethanol (co-surfactant), and that it had globule sizes of $2.397-16.8 \mathrm{~nm}$, a transparent, pseudoplastic flow, and was most stable in storage at $28 \pm 2{ }^{\circ} \mathrm{C}$. Microemulsion with $35 \%$ of Tween 80 was the most stable microemulsion formula because it had the smallest globule size, the most stable distribution profiles of globule sizes, and the highest viscosity. W/O/W multiple emulsions could formulated made with $2.5-4.5 \%$ of Tween 80 (external emulsifier) and $3 \%$ of Span 80 (internal emulsifier); these emulsions had a pseudoplastic-thixotropic flow and were most stable in storage at $28 \pm 2{ }^{\circ} \mathrm{C}$.

Conclusions: The formulation of multiple emulsions with $2.5 \%$ of Tween 80 was the most stable formula, with a stable distribution profile of globule sizes during 8 weeks of storage at temperatures of $28 \pm 2{ }^{\circ} \mathrm{C}, 4 \pm 2^{\circ} \mathrm{C}$, and $40 \pm 2^{\circ} \mathrm{C}$.

Keywords: Microemulsion, Multiple emulsions, W/O/W, $\alpha$-arbutin, Lactic acid, Niacinamide, Stability.

(C) 2017 The Authors. Published by Innovare Academic Sciences Pvt Ltd. This is an open access article under the CC BY license (http://creativecommons. org/licenses/by/4. 0/) DOI: http://dx.doi.org/10.22159/ijap.2017.v9s1.39_45

\section{INTRODUCTION}

The skin covers the entire surface of the body and is in contact with the environment. White skin has come to be regarded as a beautiful concept and associated with a healthy skin and youthful appearance [1]. Thus, it becomes the dream of most Asian women. If the skin is exposed to sunlight for a lengthy period, it becomes darker and black spots appear, due to melanin hyperpigmentation. In human skin, melanogenesis is catalyzed by tyrosinase, and several tyrosinase inhibitors have been used as skin-whitening agents in the cosmetics industry; the use of ion or tyrosinase inhibitor molecules, such as arbutin, kojic acid, mercury, and hydroquinone, will inhibit melanogenesis [2].

Alpha $(\alpha)$ arbutin is a whitening agent that inhibits the action of tyrosinase in melanogenesis, and the $\alpha$-glucoside bond in $\alpha$ arbutin results in greater efficacy than the beta ( $\beta$ )-glucoside bond in $\beta$ arbutin. It has previously been shown that $\alpha$ arbutin inhibition of tyrosinase in melanoma cells is 10 times more potent than that of $\beta$ arbutin [3]. Lactic acid, which is an alpha hydroxy acid, accelerates epidermis turnover or acts as a chemical peel. It can lighten skin by lifting the pigmented cells [4] and increasing the penetration of its active ingredients, $\alpha$ arbutin and niacinamide, which affects melanin. Niacinamide has a depigmentation effect, via the inhibition of melanosome transfer from melanocytes to keratinocytes [5]. Niacinamide can reduce the content of melanin in skin keratinocytes, making skin appear brighter [6]. It is expected that the combination of $\alpha$ arbutin, lactic acid, and niacinamide, as three active substances that have different mechanisms of action, will produce a synergistic effect in skin lightening.

Whitening cosmetics are currently formed in cream preparations. However, innovation in the emulsion technology used to formulate skin-whitening cosmetics is required to improve the delivery of active substances and thereby increase whitening effectiveness. It is also expected that innovation will allow the improvement of stability and comfort compared with the usual cream preparation. Microemulsion has thermodynamically stable characteristics, a high solubilization rate that can increase the bioavailability of the active substance, and very small particle sizes, which can accelerate microemulsion penetration of human skin layers $[7,8]$. The use of microemulsion also improves the efficacy of a drug, allowing the total dose to be reduced and thus minimizing side effects [8]. The multiple emulsions system, known as "emulsion in the emulsion" is ideal for cosmetic preparation because it can dissolve substances into three separate compartments, prolong drug release, protect active ingredients, and produce the same consistency as cream by adding a thickener in the outer phase $[9,10]$. These two dosage forms have several advantages that are considered ideal for use in cosmetics.

The present study aimed to formulate and determine the physical stability of microemulsion and W/O/W multiple emulsions, containing $\alpha$ arbutin, lactic acid, and niacinamide, as skin-whitening cosmetics. Evaluations such as an organoleptic test, and measurement of $\mathrm{pH}$, viscosity, and globule diameter were also carried out. A stability test was conducted for 8 weeks at room temperature $\left(28 \pm 2^{\circ} \mathrm{C}\right)$, low temperature $\left(4 \pm 2^{\circ} \mathrm{C}\right)$, high temperature $\left(40 \pm 2^{\circ} \mathrm{C}\right)$, and a cycling test was also performed.

\section{MATERIALS AND METHODS}

\section{Materials}

Alfa arbutin (DSM Nutritional Product, Kaiseraugst, Switzerland), lactic acid (Purac Ltd., Rayong, Thailand), niacinamide (Brataco, Jakarta, Indonesia), tocotrienol (Davos Life Science, Synapse, Singapore), isopropyl myristate (Palm Oleo Sdn. Bhd., Rawang, Malaysia), Tween 80 
(Kao Corporation, Tokyo, Japan), Span 80 (Brataco, Jakarta, Indonesia), ethanol 96\% (Brataco, Jakarta, Indonesia), propylene glycol (Brataco, Jakarta, Indonesia), xanthan gum (Cargill Bioengineering, United States), methylparaben (Ueno Fine Chemicals Industry, Hyogo, Japan), propyl paraben (Brataco, Jakarta, Indonesia), butyl hydroxytoluene (BHT) (Brataco, Jakarta, Indonesia), disodium ethylenediaminetetraacetate ( $\left.\mathrm{Na}_{2} \mathrm{EDTA}\right)$ (Brataco, Jakarta, Indonesia), sodium chloride $(\mathrm{NaCl})$ (Brataco, Jakarta, Indonesia), and aquademineralisata (Brataco, Jakarta, Indonesia).

\section{Methods}

\section{Microemulsion preparation}

Microemulsion was formulated by separately preparing the water and oil phases [11]. The water phase was divided into three parts. First, one part of aquademineralisata was used to dissolve $\alpha$ arbutin, niacinamide, lactic acids, and $\mathrm{Na}_{2}$ EDTA. Methylparaben and propylparaben were then dissolved in propylene glycol, mixed with the first part of the water phase and heated. The second part of the water phase was one part of aquademineralisata mixed with Tween 80 and heated. The remainder of the aquademineralisata was then mixed with xanthan gum to form a homogeneous gel mass into the third part of the water phase. The oil phase that consisting of isopropyl myristate, tocotrienols, and BHT, which were homogenously mixed. The oil phase was then dispersed into the water phase and heated at $50^{\circ} \mathrm{C}$, after which the two phases were mixed with a homogenizer, at a speed of $1000 \mathrm{rpm}$. Ethanol, as a volatile cosurfactant, was added to the emulsion at the beginning of the homogenization process, while xanthan gum gel was gradually added to the emulsion, while it was being stirred at a constant speed until it became homogeneous. The microemulsion was allowed to settle for 24 hrs so that its clarity could be observed.

\section{Preparation of $W / O / W$ multiple emulsions}

$\mathrm{W} / \mathrm{O} / \mathrm{W}$ multiple emulsions are generally prepared using a twostep procedure. In this study, the primary emulsion (W/O) was first prepared by adding $0.2 \mathrm{M} \mathrm{NaCl}$ solution containing $\alpha$ arbutin and niacinamide to a low hydrophile-lipophile balance surfactant solution (Span 80) at an equal volume in the oil phase, and stirring with a homogenizer $(1500 \mathrm{rpm})$ for 10 minutes. The concentration of Span 80 was 3\% wt./wt. In the second step, the W/0 primary emulsion was re-emulsified in a Tween 80 solution with a lactic acid, $\mathrm{Na}_{2} \mathrm{EDT}$, methylparaben, propylparaben, and propylene glycol in a 0.2 $\mathrm{M} \mathrm{NaCl}$ solution. The concentration of Tween 80 varied from $2.5 \%$ to $4.5 \% \mathrm{wt}$./wt and was stirred for 5 minutes at $600 \mathrm{rpm}$ to produce $\mathrm{W} / \mathrm{O} / \mathrm{W}$ multiple emulsions. Xanthan gum gel was gradually added to the $\mathrm{W} / 0 / \mathrm{W}$ multiple emulsions, during stirring at $600 \mathrm{rpm}$ until they became homogeneous.

\section{Physical evaluation of microemulsion and $W / O / W$ multiple emulsions}

Physical evaluations of the microemulsion and $\mathrm{W} / \mathrm{O} / \mathrm{W}$ multiple emulsions dosage forms included organoleptic observation, and measurement of $\mathrm{pH}$, of viscosity using a Brookfield viscometer (Brookfield Engineering Lab, Massachusetts, United States), of the average diameter of microemulsion globules using a Zetasizer Nano $S$ particle size analyzer (PSA; Malvern Instruments, Worcestershire, England), and of diameter of $\mathrm{W} / \mathrm{O} / \mathrm{W}$ multiple emulsions globules with an optical microscope and a PSA (Beckman Coulter $^{\circledR}$, California, United States). Physical stability tests were observed at temperatures of $28 \pm 2^{\circ} \mathrm{C}, 4 \pm 2^{\circ} \mathrm{C}$, and $40 \pm 2^{\circ} \mathrm{C}$ for 12 weeks, and a cycling test was also carried out for six cycles to observe the stability parameters.

\section{RESULTS AND DISCUSSION}

\section{Microemulsion}

The main experiment was carried out after obtaining the optimal microemulsion formula from the preliminary experimental results. The resulting microemulsion had a yellow color (Pantone PMS 101), clarity, and a distinctive smell. The microemulsions, F1, F2, and F3, had
$\mathrm{pH}$ values of $3.45,3.67$, and 3.85 , respectively. The tendency toward acidic $\mathrm{pH}$ was due to the use of lactic acid as an active ingredient, and $\mathrm{pH}$ value was also influenced by the amount of Tween 80 ; the higher concentration of Tween 80, the higher the $\mathrm{pH}$ value.

Measurements of the $\mathrm{pH}$ of microemulsions, which were stored for 12 weeks at room temperature $\left(28 \pm 2^{\circ} \mathrm{C}\right)$, low temperature $\left(4 \pm 2^{\circ} \mathrm{C}\right)$, and high temperature $\left(40 \pm 2^{\circ} \mathrm{C}\right)$, were taken every week. In general, all microemulsion formulas showed neither a constant value nor a drastic change (Fig. 1).

Initially, the viscosity of microemulsions F1, F2, and F3 was measured at spindle 1 , with a speed of $2 \mathrm{rpm}$, was $2100 \mathrm{cps}, 3500 \mathrm{cps}$, and $5650 \mathrm{cps}$, respectively. It suggested that a higher concentration of Tween 80 would be followed by an increase in viscosity value. The use of high concentrations of surfactants resulted in smaller dispersed phase globules, so the surface area and viscosity increased [12]. A rheogram showed that microemulsions F1, F2, and F3 had a pseudoplastic flow and viscosity measurement at weeks 4 and 8 showed declining viscosity grades. After storage for 8 weeks, the flow properties of microemulsions F1, F2, and F3 remained pseudoplastic. This indicated no change in flow properties, which meant that the microemulsions were stable for 8 weeks of storage at room temperature $\left(28 \pm 2^{\circ} \mathrm{C}\right)$.

Measurement of the average diameter of microemulsion globules was performed with a Zetasizer Nano S PSA. Microemulsions that were stored at room temperature $\left(28 \pm 2^{\circ} \mathrm{C}\right)$, low temperature $\left(4 \pm 2^{\circ} \mathrm{C}\right)$, and high temperature $\left(40 \pm 2^{\circ} \mathrm{C}\right)$ were measured at weeks 0,8 , and 12 . At week 0 , the average globule diameter of microemulsions F1, F2, and F3 was $4.44 \mathrm{~nm}, 4.27 \mathrm{~nm}$, and $2397 \mathrm{~nm}$, respectively. An increasing concentration of surfactant in the formulation was followed by a higher surface area of the dispersed phase, and smaller globule sizes. The globule size distribution curves at week 8 showed a difference in the globule size distribution profiles of microemulsions $\mathrm{F} 1$ and F2, which were stored at $4 \pm 2^{\circ} \mathrm{C}$ and $40 \pm 2^{\circ} \mathrm{C}$, while microemulsion F3 showed a particle size distribution profile that was almost similar in all preparations, irrespective of whether they were stored at $28 \pm 2^{\circ} \mathrm{C}$, $4 \pm 2^{\circ} \mathrm{C}$, or $40 \pm 2^{\circ} \mathrm{C}$, compared with their particle size distribution at week 0 . This indicates that microemulsion $\mathrm{F} 3$, which included the highest concentration of Tween 80 (35\%), had the most stable globule size distribution on storage at three different temperatures.

Organoleptic observations of the microemulsions were made every 2 weeks. Microemulsions F1, F2, and F3 that were stored at $28 \pm 2^{\circ} \mathrm{C}$ appeared clear, yellow (Pantone PMS 101), and homogeneous, and had a distinctive smell. Microemulsions F1, F2, and F3 that were stored for 12 weeks at $4 \pm 2{ }^{\circ} \mathrm{C}$ appeared to be partially frozen and a slightly murky yellow color. If they were placed back at room temperature, the microemulsions became yellow (Pantone PMS 101) and were clear, with a distinctive smell, and no phase separation. Microemulsions F1, $\mathrm{F} 2$, and $\mathrm{F} 3$ stored at $40 \pm 2^{\circ} \mathrm{C}$ from week 0 to week 12 still looked clear

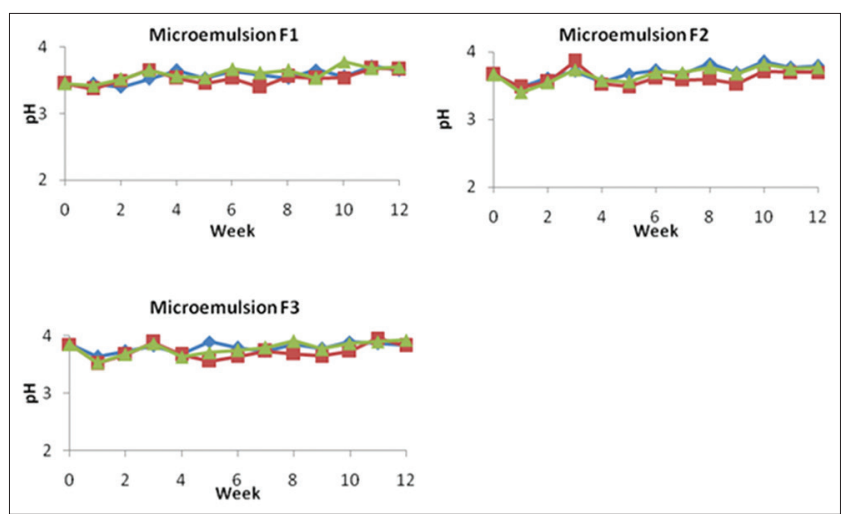

Fig. 1: $\mathrm{pH}$ evaluation of the microemulsions over 12 weeks at $28^{\circ} \pm 2^{\circ} \mathrm{C}(\square), 4^{\circ} \pm 2^{\circ} \mathrm{C}(\square)$, and $40^{\circ} \pm 2^{\circ} \mathrm{C}(-)$ 
were yellow (Pantone PMS 101), had a distinctive smell, and no phase separation. Following a cycling test using as many as six cycles, the microemulsions remained clear, stable, and yellow (Pantone PMS 101), with a distinctive smell. Microscopic observation showed that there were no crystals in the microemulsions.

\section{W/O/W multiple emulsions}

The main experiment was carried out after obtaining the optimal formula for multiple emulsions from preliminary experiments. The $\mathrm{W} / \mathrm{O} / \mathrm{W}$ multiple emulsions were white- yellowish in color (Pantone PMS 607), homogeneous, and odorless. When applied to the skin, the W/O/W multiple emulsions felt cool and comfortable.

At week 0 , the $\mathrm{pH}$ values of the multiple emulsions $\mathrm{F} 1, \mathrm{~F} 2$, and F3 were $3.31,3.35$, and 3.35 , respectively. In general, the $\mathrm{pH}$ measurements of multiple emulsions preparations that were stored for 8 weeks at room temperature $\left(28 \pm 2^{\circ} \mathrm{C}\right)$, low temperature $\left(4 \pm 2^{\circ} \mathrm{C}\right)$, and high temperature $\left(40 \pm 2^{\circ} \mathrm{C}\right)$ did not show a constant value, but the $\mathrm{pH}$ range did not drastically change. The $\mathrm{pH}$ values of the multiple emulsions ranged from 3.02 to 3.35; the presence of lactic acid in the formula resulted in acidic multiple emulsions. The $\mathrm{pH}$ measurements are shown in Fig. 2.

At week 0 , multiple emulsions F1, F2, and F3 with spindle 3 at a speed of $2 \mathrm{rpm}$, had viscosities of $9500 \mathrm{cps}, 10,000 \mathrm{cps}$ and 10,500 cps, respectively. A tendency for a higher concentration of Tween 80 to result in a higher viscosity value was also shown. A high concentration of emulsifier would further reduce the size of globule diameter. A rheogram of multiple emulsions F1, F2, and F3 at week 0 indicates that those formulae had a pseudoplastic thixotropic flow. This showed decreasing viscosity, which was not immediately rectified when stress was not eliminated or reduced [12]. The viscosity measurements of multiple emulsions that were performed at weeks 4 and 8 showed a decline in viscosity grades. After storage for 12 weeks at room temperature $\left(28 \pm 2^{\circ} \mathrm{C}\right)$, multiple emulsions $\mathrm{F} 1, \mathrm{~F} 2$, and $\mathrm{F} 3$ still had a pseudoplastic thixotropic flow.

The average globule diameters of multiple emulsions were measured at 1000 times magnification, using an optical microscope equipped with a scale. At week 0 , the globules of multiple emulsions F1, F2, and F3 had internal average diameters of $0.293,0.292$ and $0.284 \mu \mathrm{m}$, respectively, while the external globules had diameters of $0.605,0.566$, and $0.517 \mu \mathrm{m}$, respectively. The average globule diameter of F3 was smaller than those of F2 and F1, because of the concentration of Tween 80 that was most widely used in multiple emulsions F3; the higher the concentration of emulsifier, the smaller the globule size [13]. The microscopic measurements showed that multiple emulsions stored for 8 weeks at room temperature $\left(28 \pm 2^{\circ} \mathrm{C}\right)$, low temperature $\left(4 \pm 2^{\circ} \mathrm{C}\right)$, and high temperature $\left(40 \pm 2^{\circ} \mathrm{C}\right)$ had changes in their globule size which tended to increase. It is because coalescence between the droplet phase in and phase out, which could be minimized using $\mathrm{NaCl}$ to maintain the same osmotic pressure between the internal and external water phases [14]. The multiple emulsions globules are shown in Fig. 3.

Measurements of the external globules of the multiple emulsions were also taken at week 8, using a PSA (Beckman Coulter ${ }^{\circledR}$ ), but these measurements could only show the external diameter of the globules. It was found that multiple emulsion F1, with the lowest concentration of Tween $80(2.5 \%)$, had globule size distribution profiles that tended to be stable after 8 weeks of storage at $28 \pm 2^{\circ} \mathrm{C}, 4 \pm 2^{\circ} \mathrm{C}$, and $40 \pm 2^{\circ} \mathrm{C}$. Multiple emulsion F3, with the highest concentration of Tween $80(4.5 \%)$, showed different distribution profiles of globule sizes at the three storage temperatures. The average external globule diameters measured via PSA are shown in Table 1.

Multiple emulsions of F1, F2, and F3 that had been stored at low temperatures from week 0 to week 12 still looked white-yellowish in color (Pantone PMS 607), had no change in odor, and no visible phase separation. Multiple emulsions F1, F2, and F3 that had been stored at

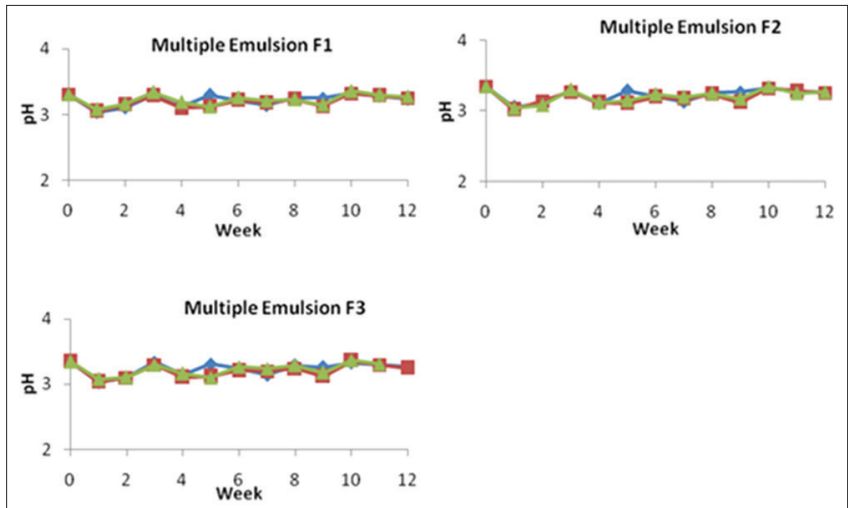

Fig. 2: $\mathrm{pH}$ evaluation of the $\mathrm{W} / \mathrm{O} / \mathrm{W}$ multiple emulsions during 8 weeks at $28^{\circ} \pm 2^{\circ} \mathrm{C}(-), 4^{\circ} \pm 2^{\circ} \mathrm{C}(-)$, and $40^{\circ} \pm 2^{\circ} \mathrm{C}(-)$

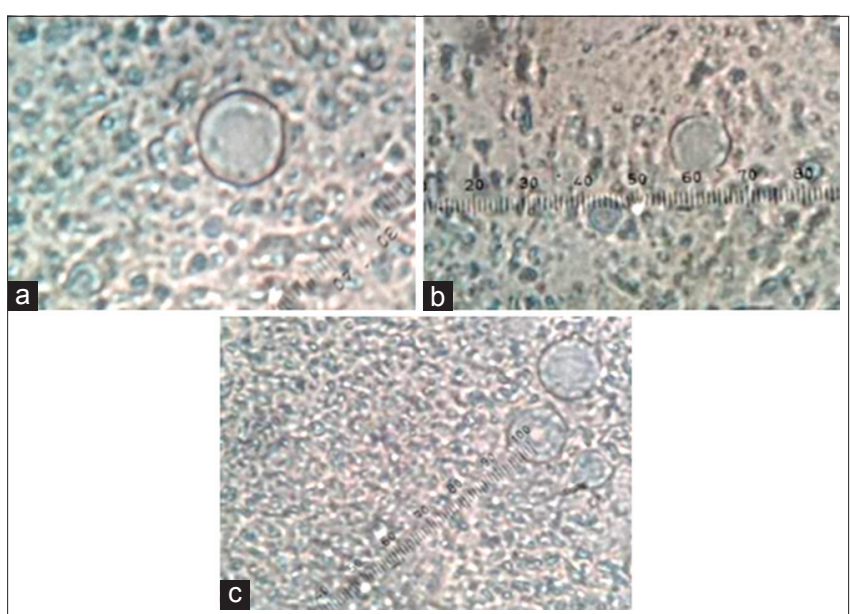

Fig. 3: (a-c) Multiple emulsions globules of F1, F2, and F3 at week 0 under a microscope with $\times 1000$ magnification

Table 1: The average external globule diameters of multiple emulsions at week 8

\begin{tabular}{llll}
\hline Formula & \multicolumn{2}{l}{$\begin{array}{l}\text { Average globule diameter }(\boldsymbol{\mu m}) \text { at } \\
\text { week-8 }\end{array}$} \\
\cline { 2 - 4 } & $\mathbf{2 8 \pm 2 ^ { \circ } \mathbf { C }}$ & $\mathbf{4 \pm 2}{ }^{\circ} \mathbf{C}$ & $\mathbf{4 0 \pm 2}^{\circ} \mathbf{C}$ \\
\hline Multiple emulsion F1 & 2.425 & 1.830 & 2.345 \\
Multiple emulsion F2 & 1.473 & 1.686 & 1.710 \\
Multiple emulsion F3 & 1.751 & 1.824 & 1.808 \\
\hline
\end{tabular}

high temperatures from week 0 to week 8 still appeared to be yellowishwhite, had no smell, and had no visible phase separation. However, in multiple emulsions $\mathrm{F} 3$ that had been stored at a temperature of $40 \pm 2^{\circ} \mathrm{C}$, there was a significant yellow color on the upper surface of the preparation. This may have been the result of the hydrophilic surfactant in the continuous aqueous phase beyond the critical micelle concentration so that the lipophilic surfactant micelles solubilized lipophilic surfactant and removed it from the water continuous phase [14]. High temperatures could accelerate this phenomenon, resulting in decreased concentrations of lipophilic surfactant in the oil phase, and rupturing of the oil layer, thereby explaining the yellow color on the upper surface of the preparation. Cycling test results from six cycles of the three multiple emulsions formulae showed that the preparation remained white-yellow (Pantone PMS 607) and there was no change in odor. Multiple emulsions preparations F1, F2, and F3 were stable without any phase separation. Microscopy showed that there were no crystals in the multiple emulsions preparations. 


\section{CONCLUSION}

Microemulsion with $\alpha$ arbutin, lactic acid, and niacinamide which was formulated with surfactant (Tween 80 ) at concentrations of $25 \%, 30 \%$, and $35 \%$, was clear and had a yellowish color, a pseudoplastic flow, an average globule size $<100 \mathrm{~nm}$, and was stable. Microemulsion F3, with a Tween 80 concentration of $35 \%$, was the most stable formula because it had the smallest average globule size $(2.397 \mathrm{~nm})$ and the most stable distribution profile of globule size following 12 weeks of storage at $28 \pm 2^{\circ} \mathrm{C}, 4 \pm 2^{\circ} \mathrm{C}$, and $40 \pm 2^{\circ} \mathrm{C}$.

$\mathrm{W} / \mathrm{O} / \mathrm{W}$ multiple emulsions with $\alpha$ arbutin, lactic acid, and niacinamide could be formulated with $2.5 \%, 3.5 \%$, and $4.5 \%$ of Tween 80 (external emulsifier), and also $3 \%$ of Span 80 (internal emulsifier) with a yellowish-white color, a pseudoplastic thixotropic flow, and internal and external globules, which could be clearly observed on microscopic observation. Multiple emulsions F1 with 2.5\% Tween 80 was the most stable formula because it had a stable distribution profile of globule size during 12 weeks of storage at $28 \pm 2^{\circ} \mathrm{C}, 4 \pm 2^{\circ} \mathrm{C}$, and $40 \pm 2^{\circ} \mathrm{C}$.

\section{REFERENCES}

1. Dixit GR, Mathur VB. Microemulsions: Platform for improvement of solubility and dissolution of poorly soluble drugs. Asian J Pharm Clin Res 2015;8(5):7-17.

2. Maeda K. In vitro effectiveness of several whitening cosmetic components in human melanocytes. $\mathrm{J}$ Soc Cosmet Chem 1991;42(6):361-8

3. Funayama M, Arakawa H, Yamamoto R, Nishino T, Shin T, Murao S. Effects of alpha-and beta-arbutin on activity of tyrosinases from mushroom and mouse melanoma. Biosci Biotechnol Biochem 1995;59(1):143-4.

4. Usuki A, Ohashi A, Sato H, Ochiai Y, Ichihashi M, Funasaka Y. The inhibitory effect of glycolic acid and lactic acid on melanin synthesis in melanoma cells. Exp Dermatol 2003;12 Suppl 2:43-50.

5. Hakozaki T, Minwalla L, Zhuang J, Chhoa M, Matsubara A, Miyamoto K, et al. The effect of niacin amide on reducing cutaneous pigmentation and suppression of melanosome transfer. Br J Dermatol 2002;147(1):20-31.

6. Castanedo-Cazares JP, Larraga-Pinones G, Ehniz-Perez A, FuentesAhumada C, Oros-Ovalle C, Smoller BR, et al. Topical $4 \%$ and desonide $0.05 \%$ for treatment of axillary hyperpigmentation: A randomized, multiple-blind, placebo-controlled study. Clin Cosmet Investig Dermatol 2013;6:29-36.

7. Lawrence MJ, Rees GD. Microemulsion-based media as novel drug delivery systems. Adv Drug Deliv Rev 2000;45(1):89-121.

8. Arsiwala S, Tahiliani S, Jerajani H, Chandrashekhar BS, Aurangabadkar S, Kohli M, et al. Evaluation of image blanc complexion lightner and image blanc spot lightner for hyperpigmentation in face and neck. Asian J Pharm Clin Res 2013;6(3):90-3.

9. Tadros TF. Future developments in cosmetic formulations. Int J Cosmet Sci 1992;14(3):93-111.

10. Akhtar N, Ahmad M, Khan HM, Akram J, Gulfishan G, Mahmood $\mathrm{A}$, et al. Formulation and characterization of a multiple emulsions containing 1\% L-ascorbic acid. Bull Chem Soc Ethiop 2010;24:1-10.

11. Jadhav KR, Shetye SL, Kadam VJ. Design and evaluation of microemulsion based drug delivery system. Int J Adv Pharm Sci 2010;1(2):156-6.

12. Martin A, Swarbick J, Cammarata A. Physical Pharmacy. $3^{\text {rd }}$ ed. (Joshita, tranl.). Jakarta: UI Press; 2008.

13. Koocheki A, Kadkhodaee R. Effect of alyssum homolocarpum seed gum, tween 80 and $\mathrm{NaCl}$ on droplets characteristics, flow properties and physical stability of ultrasonically prepared corn oil-in-water emulsions. Food Hydrocoll 2011;25:1149-57.

14. Jiao J, Burgess DJ. Rheology and stability of water-in-oil-in-water multiple emulsions containing Span 83 and Tween 80. AAPS PharmSci 2003;5(1):E7 